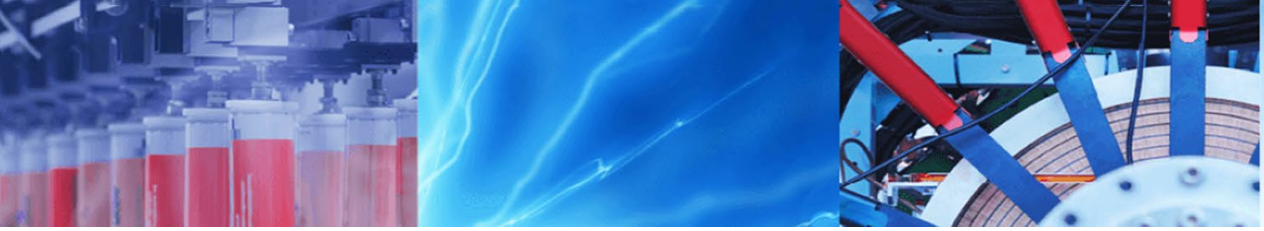

Research Article

\title{
Heavy metal pollution in suburban topsoil of Nyeri, Kapsabet, Voi, Ngong and Juja towns, in Kenya
}

\author{
Teresiah Muciku Mungai ${ }^{1,3,4}$. Jun Wang ${ }^{2,3}$
}

C) Springer Nature Switzerland AG 2019

\begin{abstract}
The increasing industrialization and agricultural developments in suburban areas of Kenya, has increased the threat of heavy metal contamination in soil. Until now, there are limited studies evaluating metal pollution in suburban towns. This study, therefore, investigated the concentration, distribution and environmental risk of lead (Pb), chromium (Cr), copper (Cu), nickel (Ni), zinc ( $\mathrm{Zn})$, mercury $(\mathrm{Hg})$, arsenic $(\mathrm{As})$ and cadmium $(\mathrm{Cd})$ in five townships. Heavy metal source apportionment was examined using principal component analysis and validated using cluster analysis. The relationship between heavy metals was analyzed using Pearson's correlation test and the ecological risk index calculated to determine the degree of contamination. The concentrations of heavy metals were 1.65-99.16, 0.2-12.50, n.d. (not detected) -2.28 , $0.59-17.22,0.18-4.93,0.17-1.55,0.01-0.23$ and n.d. $-0.03 \mathrm{mg} \mathrm{kg}^{-1}$ for $\mathrm{Zn}, \mathrm{Pb}, \mathrm{As}, \mathrm{Cu}, \mathrm{Cr}, \mathrm{Ni}, \mathrm{Cd}$, and $\mathrm{Hg}$, respectively. These values were within the toxicity limit of Tanzania soil guidelines. The results further demonstrated that natural and anthropogenic activities influenced the distribution of heavy metals. Correlation coefficients highlighted an association among heavy metals suggesting a similar origin. Pollution indices revealed that pollution decreased in the order Juja $>$ Ngong $>$ Kapsabet $>$ Nyeri $>$ Voi with the overall ecological index indicating a low level of pollution. The concentration of $\mathrm{As}$ and $\mathrm{Pb}$ were found to be high in all the study sites posing a potential hazard to the environment while Juja and Ngong regions were at a higher risk of threat. The inappropriate disposal of industrial and municipal effluents, agricultural practices, and burning of fossil fuels, was identified as the key causes of metal pollution.
\end{abstract}

Keywords Concentrations · Contamination · Ecological risk $\cdot$ Heavy metals $\cdot$ Kenya $\cdot$ Topsoil

Mathematics Subject Classification $62 \mathrm{Hxx} \cdot 62 \mathrm{H} 10 \cdot 62 \mathrm{H} 20 \cdot 62 \mathrm{H} 25 \cdot 62 \mathrm{H} 30$

JEL Classification Q5 Q Q53

\section{Introduction}

Environmental pollution from heavy metals is continually increasing in developing countries resulting in high concentrations of trace elements in the soil [1]. The soil pollution from heavy metals in these areas has been mainly linked to the expanding urbanization and industrialization activities [2]. In Africa, heavy metal pollution results from natural sources, including weathering of rocks and the tectonic movement of the earth. Human activities also contribute to the dissemination of pollutants in the surroundings leading to toxic pollution in major cities [3]. Some of the anthropogenic activities include; improper disposal of municipal waste, and domestic effluent, agricultural

$\triangle$ Jun Wang, wangjun2016@scau.edu.cn | ${ }^{1}$ Key Laboratory of Aquatic Botany and Watershed Ecology, Wuhan Botanical Garden, Chinese Academy of Sciences, Wuhan 430074, China. ${ }^{2}$ College of Marine Sciences, South China Agricultural University, Guangzhou 510642, China. ${ }^{3}$ Sino-Africa Joint Research Center, Chinese Academy of Sciences, Wuhan 430074, China. ${ }^{4}$ University of Chinese Academy of Sciences, Beijing 100049, China. 
fertilizers, mining activities, small-scale manufacturing industries, burning of fossil fuel, and vehicular traffic emissions [4-6]. Additionally, human interference with the biogeochemical systems of the earth, lead to the enhanced release of naturally occurring heavy metals into the environment and soils act as the significant sink [7]. Over time, these heavy metals accumulate and remain in the soil medium for an extended period owing to their persistent nature [8]. Humans and animals are then exposed through inhalation, ingestion, and from direct contact with contaminated soils [9]. Plants grown on this polluted soils take up the heavy metals, and through the bio, magnification enters the food chain [10]. Moreover, a decline in plant development and yield was observed in plants grown on heavy metal contaminated soils, indicating a decrease in food production [11]. Some of the toxic heavy metals include lead $(\mathrm{Pb})$, chromium $(\mathrm{Cr})$, copper $(\mathrm{Cu})$, nickel $(\mathrm{Ni})$, zinc ( $\mathrm{Zn})$, mercury $(\mathrm{Hg})$, arsenic (As), and cadmium (Cd).

Previously, heavy metals have been documented in various environment, posing concerns to human well-being [12-15], and animal health [16, 17]. In areas with intensive industrialization activities, children are especially at a higher risk of exposure to these potentially toxic elements through soil [18]. Research on the metal pollution of suburban areas has also been done in different countries, and elevated levels of heavy metals in the soils were recorded [19-21]. The soil pollution of these cities was primarily associated with industrial and municipal effluents.

In Kenya, the suburban towns are some of the areas experiencing rapid population growth and development. However, these townships are faced with inadequate planning, which transforms into an imbalance in economic growth, and environmental sustainability is a challenge [22]. Monitoring of heavy metals in these areas is therefore crucial as their concentrations in soils affect the plants and water ecosystems, which are vital resources to livelihood [23]. Recently, the use of chemicals in manufacturing and agricultural sectors has increased, contributing to environmental contamination of natural resources and a decrease in biodiversity [24]. Moreover, the continuous utilization of pesticides in farms, lack of proper waste management systems, and the improper disposal of waste in the country raise concerns on pollutants in the environment [25]. For instance, in the suburban setting, there is rapid economic growth, coupled with the emergence of factories and industries. The problem of population upsurge and the increased use of motor vehicles have also become very rampant [3]. This upward trend in development makes townships significant areas for assessment of contamination. It is particularly important to examine the potential ecological danger and predict the contamination trend of metal elements in these soils to mitigate and establish legislative policies for environmental protection. However, no studies have focused primarily on suburban areas in Kenya hence the purpose of this study. The information obtained will, therefore, be useful toward the sustainable management and protection of the environment. This study was thus formulated to provide comprehensive data on heavy metal contamination in top suburban soils of Kenya. The concentration levels of eight significant heavy metals including, $\mathrm{Pb}, \mathrm{Cr}, \mathrm{Cu}, \mathrm{Ni}, \mathrm{Zn}, \mathrm{Hg}$, As and $\mathrm{Cd}$, were determined. Heavy metal sources were assessed to ascertain the origin of the contamination. Social and environmental potential risks were evaluated by comparing the findings in this study with other studies and with the Tanzania soil quality guidelines. Moreover, the potential ecological risk index was calculated to provide ample information on the probable risk posed to the surroundings.

\section{Materials and methods}

\subsection{Study area}

Soil sampling was collected randomly from five different counties including; Thika (Kiambu County), Ngong (Kajiado County), Kapsabet (Nandi County), Voi (Taita Taveta County), and Nyeri (Nyeri County) (Fig. 1). The study areas were chosen as representatives of various parts of the country for comparison purposes. The sampling sites focused on locations influenced by anthropogenic activities from intensive farming activities through the utilization of agrochemicals. The areas are also characterized by a high population influx with rapid economic development coupled with growth in infrastructure and the rise of industries.

The first study site is Ngong town, a well-developed suburb where crop farming and livestock rearing are the main economic activities. In the area, there exists a dumpsite where tons of waste is deposited in vast acres of land. Burning of wastes and plastics are some of the significant soil pollution sources in the area. Use of animal waste and commercial fertilizers in the farms was also noted. Vegetables grown near the waste dumpsite were primarily cultivated using wastewater. The use of firewood-based stoves and charcoal for cooking was observed in the densely populated Mathare slum in the area. The second study area is Kapsabet, an agricultural town where tea and corn are grown mainly hence the utilization of agrochemicals. The region also has an open dumpsite where solid waste is disposed of haphazardly, causing severe pollution. Moreover, the open burning of wastes and the use of fossil fuel in households are frequent. The third study site is Voi, a major transport service town located along the Nairobi-Mombasa highway. Voi area is prone to high automobile fuel emissions from the heavy commercial vehicles that frequent this route. The 


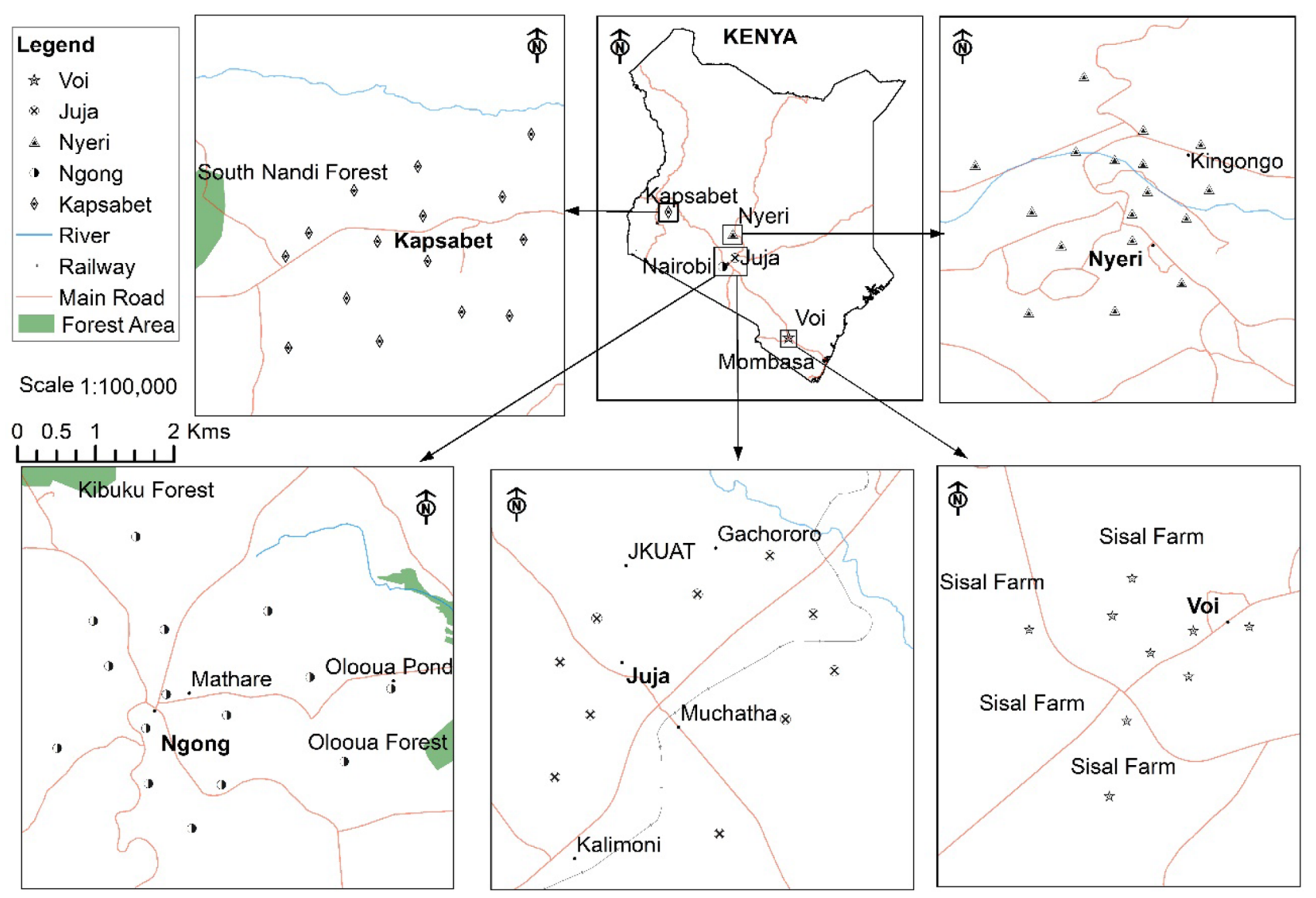

Fig. 1 Map of sampling points showing Juja, Ngong, Kapasabet, Voi, and Nyeri townships

community in the region grows sisal on a large scale, along with other food crops hence the use of pesticides and fertilizers to increase production. Household wastewater from the area is disposed of in shallow trenches resulting in pollution of soil. The fourth site is Juja Town. Juja is witnessing rapid growth with the recent construction of the Thika Highway. However, the traffic emissions in the area have increased, linked to the use of $\mathrm{Pb}$ gasoline fuel. Alongside the busy road, there are apartments and hotels increasing pollution from household wastewater attributable to the poor drainage in the area. Lastly, Nyeri is an agricultural town with large-scale farming of tea and coffee. Besides, both small- and large-scale farming of corn and dairy farms are also present. The area also comprises of several factories involved in coffee and tea production for export [26]. Burning of waste, including animal waste, maize cobs, coffee, and tea prunes, is frequent.

\subsection{Sample collection, preparation, extraction, and analysis}

Sixty-six samples were collected from different sites as follows; Juja (10), Ngong (15), Kapsabet (15), Voi (9) and,
Nyeri (17). The topsoil (0-30 cm depth) was sampled using a small shovel and packed in zip lock bags. The heavy metals were extracted using a method previously reported by Mungai et al. [6]. Sample preparation involved the following steps: approximately five grams of the resultant sample was freeze-dried at high pressure, pulverized, and sifted using a 60 -mesh sieve [27]. About $0.15 \mathrm{~g}$ of the soil sample was transferred into digestion tubes where $4 \mathrm{~mL}$ nitric acid and $2 \mathrm{~mL}$ hydrofluoric acid was added. The resultant homogenous mixture was then placed in the microwave digestion system (milestone ethos one) at regulated temperature and pressure for $2 \mathrm{~h}$ for decomposition to occur. The digested samples were afterward placed on a hot plate at $180^{\circ} \mathrm{C}$ for solutions to vaporize. After cooling, the residues were transferred into conical flasks where double distilled water was added to the $50 \mathrm{~mL}$ mark and then filtered using $0.45 \mu \mathrm{m}$ filters to remove any solid matter. The target heavy metals were then analyzed using the inductively coupled plasma -mass spectrometer (ICPMS). The use of ICP-MS method has the advantage of high sensitivity and precision. This method allows for quantification of trace concentrations of heavy metals with accuracy at a comprehensive linear array. About $0.005 \mathrm{~g}$ of the 
sample was bounded in a tin foil and placed in the TOC Analyzer (Elementar, Inc., Germany) to examine the total organic carbon (TOC) levels in the soil.

\subsection{Quality assurance and quality control}

The Inductively Coupled Plasma-Mass Spectrometer machine was calibrated to assess the response factor and evaluate instrumental precision. Cross-contamination was evaluated by running a routine blank and a spiked sample containing the analytes to check for interference. The glassware used in the experiment was first soaked in $(5 \%$ $\mathrm{v} / \mathrm{v}$ ) nitric acid and afterward cleaned thoroughly using double distilled water and finally dried in the kiln before use. All the samples were tested in triplicates for accuracy. Standard solutions for the tested heavy metals showed relative coefficients standard curves greater than 0.9933 .

\subsection{Risk assessment}

The Hakanson potential ecological risk index (PERI) was used to determine the threat posed by heavy metals in soil. This method takes into account the set background soil standard values to analyze the potential environmental risk of the heavy metal in soil. In our study, soil background values for Kenya are not available, and hence, Tanzanian soil background values were used for reference. The pollution risk index is thus given by the overall sum of the ecological threat of a single heavy metal in the soil [28]. In this study, the heavy metal potential hazard was calculated for, $\mathrm{As}, \mathrm{Pb}, \mathrm{Hg}, \mathrm{Cd}, \mathrm{Cr}, \mathrm{Ni}, \mathrm{Cu}$, and $\mathrm{Zn}$. The formulas used to quantify the heavy metals were as follows [29].

$C_{f}^{i}=C_{\text {surface }}^{i} / C_{\text {reference }}^{i}$

The contamination factor $C_{f}^{i}$ represents the pollution index of a single metal element which can reflect the pollution character of the investigated region but cannot reveal the ecological effects and hazards. $C_{\text {surface }}^{i}$ refers to the obtained content of heavy metals in our study soils. While $C_{\text {reference }}^{i}$ gives the contextual set soil quality guidelines of the heavy metals. Due to the absence of soil reference standards of heavy metals in Kenya, Tanzania soil background values were used as a reference.

To determine the toxicity of a single heavy metal $\left(E_{f}^{i}\right)$ the following formula was used;

$E_{f}^{i}=C_{f}^{i} \times T_{f}^{i}$

where $T_{f}^{i}$ refers to the toxicity response aspect for a single heavy metal. This method typically discloses the threats posed by heavy metals on human health and the surrounding environment and reveals the metal toxicity degree and ecological sensitivity to the heavy metal pollution. The method takes into account the homogeneous response factor of heavy metals based on toxicity. The response factor values include $5,2,5,1,5,10,30$, and 40 for $\mathrm{Ni}, \mathrm{Cr}, \mathrm{Cu}, \mathrm{Zn}, \mathrm{Pb}, \mathrm{As}, \mathrm{Cd}$, and $\mathrm{Hg}$, respectively, as specified by Hakanson [28]. The $E_{f}^{i}$ is then calculated by the product of the contamination factor and the toxicity factor, defined as the probable risk factor for single heavy metal. To further examine the overall pollution of the different areas, the calculated $E_{f}^{i}$ value is then analyzed using the descriptive categories defined by Hakanson [29]. Where, $E_{f}^{i}<40$, defines low environmental risk; $40 \leq E_{f}^{i}<80$, moderate risk; $80 \leq E_{f}^{i}<160$, considerable risk; $E_{f}^{i}<320$, high risk; and $E_{f}^{i} \geq 320$, very high environmental risk.

Lastly, the RI value which symbolizes the integrated single heavy metal contamination factor values is given by

$\mathrm{RI}=\sum_{f}^{i} E_{f}^{i}$

Similarly, the $\mathrm{RI}$ value is grouped into four grades $\mathrm{RI}<150$, indicates minimal environmental risk; $150 \leq \mathrm{Rl}<300$, reasonable environmental risk; $300 \leq \mathrm{Rl}<600$, substantial risk; and $\mathrm{RI} \geq 600$, very high environmental risk.

\subsection{Statistical analysis}

The data were explored using SPSS 21.0 software, Microsoft Excel 2010, and Origin data analysis, and graphing software. All statistical variations were considered significant at the $p<0.05$ level. The association between heavy metals and TOC was evaluated using Pearson's correlation analysis [30]. Pearson correlation test was used as a measure of linearity, and heavy metals with good association were grouped indicating a similar source of pollution. To further determine the pollution sources, principal component analysis (PCA) using varimax rotation $[31,32]$ was used and corroborated with hierarchical cluster analysis according to Ward's technique with Euclidean distances $[33,34]$. PCA was applied to extract significant variables. The varimax rotation amplified the entities of element loadings values across the measured variables, and the varimax factors with loading components of $\geq 0.5$ were considered. HCA was used for sorting of similar metal elements into clusters, where the number of groups either emanates from an anthropogenic or natural source. To assess the intensity of metals in the soil, the average, standard deviation, and range values were calculated. 


\section{Results}

\subsection{Concentration of heavy metals in soil}

In the five suburban towns studied, the concentration of all the tested heavy metals is presented in Table 1. The mean values of $\mathrm{Zn}, \mathrm{Pb} \mathrm{As}, \mathrm{Cu}, \mathrm{Cr}, \mathrm{Ni}, \mathrm{Cd}$, and $\mathrm{Hg}$ in the soils were $9.3 \pm 12.54,1.92 \pm 2.13,0.70 \pm 0.73,2.01 \pm 2.23$, $0.84 \pm 0.7,0.58 \pm 0.30,0.06 \pm 0.04$, and $0.01 \pm 0.01 \mathrm{mg} \mathrm{kg}^{-1}$, respectively. The overall concentration ranges of the eight heavy metals were observed to be $1.65-99.16,0.2-12.50$, n.d-2.28, 0.59-17.22, 0.18-4.93, 0.17-1.55, 0.01-0.23 and n.d. $-0.03 \mathrm{mg} \mathrm{kg}^{-1}$ for $\mathrm{Zn}, \mathrm{Pb} \mathrm{As}, \mathrm{Cu}, \mathrm{Cr}, \mathrm{Ni}, \mathrm{Cd}$, and $\mathrm{Hg}$, respectively. The heavy metal concentrations fell within the set Tanzania standard values. The total organic matter in the soil ranged from 0.03 to $2.65 \%$.

Among the tested heavy metals, the pollution by As was high in Juja compared to the other study sites with a mean of $1.59 \pm 0.36$ (range 1.06-2.28 $\mathrm{mg} \mathrm{kg}^{-1}$ ). In Ngong town, the high mean concentration of $\mathrm{Zn}$ and $\mathrm{Cu}$ was observed (Table 1). The levels of $\mathrm{Ni}$ and $\mathrm{Hg}$ were found to be relatively higher in Kapsabet than all the other studied areas. The soils from Nyeri exhibited the highest levels of $\mathrm{Zn}, \mathrm{Pb}, \mathrm{Cu}, \mathrm{Cr}$, and $\mathrm{Cd}$. Overall, $\mathrm{Zn}$ showed high concentration values in the soils of all the studied areas with a mean of $9.3 \pm 12.54 \mathrm{mg} \mathrm{kg}^{-1}$. Its maximum concentration $\left(99.16 \mathrm{mg} \mathrm{kg}^{-1}\right)$ was observed in Nyeri town.

\subsection{Heavy metal source apportionment}

Heavy metals source distribution was determined using PCA. PCA is a statistical tool that helps in grouping data according to their related patterns and identifying sources of metals in the surroundings [32]. In our study, PCA was carried out to define the source apportionment of the eight heavy metals tested for the study areas using the Varimax method (Table 2). Two principal components (PC) with eigenvalues of 3.740 and 2.278 were extracted, which explained an overall variance of $75.228 \%$. PC1 accounted for $46.748 \%$ of the total variance with high scores of $\mathrm{Ni}$, As, Cd and Hg (Fig. 2) defining the lithogenic factor. PC2

Table 2 Rotation sums of squared loading of heavy metals for principal component matrix

\begin{tabular}{llll}
\hline Component & Eigenvalues & \% of Variance & Cumulative \% \\
\hline 1 & 3.740 & 46.748 & 46.748 \\
2 & 2.278 & 28.479 & 75.228 \\
\hline
\end{tabular}

Extraction method: principal component analysis

Rotation method: Varimax with Kaiser normalization

Table 1 Average concentration levels, range, and standard deviation of heavy metals in suburban soils of Kenya and the standard background values of Tanzania $\left(\mathrm{mg} \mathrm{kg}^{-1}\right)$

\begin{tabular}{|c|c|c|c|c|c|c|c|c|c|}
\hline & $\mathrm{Zn}$ & $\mathrm{Pb}$ & As & $\mathrm{Cu}$ & $\mathrm{Cr}$ & $\mathrm{Ni}$ & $\mathrm{Cd}$ & $\mathrm{Hg}$ & TOC (\%) \\
\hline \multicolumn{10}{|l|}{ Juja $(n=10)$} \\
\hline Range & $4.22-5.93$ & $1.20-1.75$ & $1.06-2.28$ & $0.64-2.68$ & $0.77-2.61$ & $0.39-1.12$ & $0.07-0.10$ & $0.02-0.03$ & $0.05-0.63$ \\
\hline Mean $\pm S D^{a}$ & $5.12 \pm 0.59$ & $1.51 \pm 0.16$ & $1.59 \pm 0.36$ & $1.61 \pm 0.68$ & $1.43 \pm 0.56$ & $0.75 \pm 0.26$ & $0.09 \pm 0.01$ & $0.02 \pm 0.00$ & $0.24 \pm 0.05$ \\
\hline \multicolumn{10}{|l|}{ Ngong $(n=15)$} \\
\hline Range & $3.64-14.54$ & $0.73-1.31$ & $0.35-2.13$ & $0.99-5.35$ & $0.26-1.87$ & $0.32-1.21$ & $0.05-0.11$ & $0.01-0.02$ & $0.07-1.29$ \\
\hline Mean $\pm S D$ & $6.28 \pm 2.74$ & $0.98 \pm 0.20$ & $1.30 \pm 0.46$ & $2.20 \pm 1.17$ & $0.83 \pm 0.48$ & $0.71 \pm 0.25$ & $0.08 \pm 0.01$ & $0.02 \pm 0.00$ & $0.34 \pm 0.08$ \\
\hline \multicolumn{10}{|l|}{ Kapsabet $(n=15)$} \\
\hline Range & $3.42-35.84$ & $0.42-7.69$ & $n \cdot d^{b} \cdot-1.72$ & $0.59-2.33$ & $0.22-1.35$ & $0.23-1.55$ & $0.01-0.10$ & n.d. -0.03 & $0.03-1.71$ \\
\hline Mean \pm SD & $10.55 \pm 9.47$ & $2.05 \pm 2.07$ & $0.67 \pm 0.57$ & $1.45 \pm 0.44$ & $0.82 \pm 0.32$ & $0.68 \pm 0.40$ & $0.05 \pm 0.02$ & $0.01 \pm 0.01$ & $0.51 \pm 0.13$ \\
\hline \multicolumn{10}{|l|}{ Voi $(n=9)$} \\
\hline Range & $1.65-17.83$ & $0.2-7.79$ & n.d-0.21 & $0.86-1.58$ & $0.18-0.58$ & $0.17-0.41$ & $0.01-0.02$ & n.d. -0.01 & $0.25-1.25$ \\
\hline Mean \pm SD & $6.69 \pm 4.97$ & $2.15 \pm 2.93$ & $0.10 \pm 0.09$ & $1.09 \pm 0.26$ & $0.36 \pm 0.13$ & $0.29 \pm 0.09$ & $0.01 \pm 0.00$ & $0.01 \pm 0.00$ & $0.56 \pm 0.13$ \\
\hline \multicolumn{10}{|l|}{ Nyeri $(n=17)$} \\
\hline Range & $4.84-99.16$ & $0.43-12.50$ & n.d-0.24 & $1.09-17.22$ & $0.32-4.93$ & $0.32-0.73$ & $0.02-0.23$ & n.d-0.02 & $0.23-2.65$ \\
\hline Mean $\pm S D$ & $14.70 \pm 22.03$ & $2.68 \pm 2.92$ & $\mathrm{n} . \mathrm{d} \pm 0.20$ & $3.12 \pm 4.07$ & $0.76 \pm 1.08$ & $0.44 \pm 0.12$ & $0.05 \pm 0.05$ & $0.01 \pm 0.00$ & $0.9 \pm 0.20$ \\
\hline \multicolumn{10}{|l|}{ Overall } \\
\hline Range & $1.65-99.16$ & $0.2-12.50$ & n.d-2.28 & $0.59-17.22$ & $0.18-4.93$ & $0.17-1.55$ & $0.01-0.23$ & n.d. -0.03 & $0.03-2.65$ \\
\hline Mean \pm SD & $9.3 \pm 12.54$ & $1.92 \pm 2.13$ & $0.70 \pm 0.73$ & $2.01 \pm 2.23$ & $0.84 \pm 0.7$ & $0.58 \pm 0.30$ & $0.06 \pm 0.04$ & $0.01 \pm 0.01$ & \\
\hline Tanzania standard values & 150 & 200 & 20 & 200 & 100 & 100 & 1 & 2 & [63] \\
\hline
\end{tabular}

${ }^{\text {a }}$ Standard deviation

${ }^{b}$ n.d. not detected 


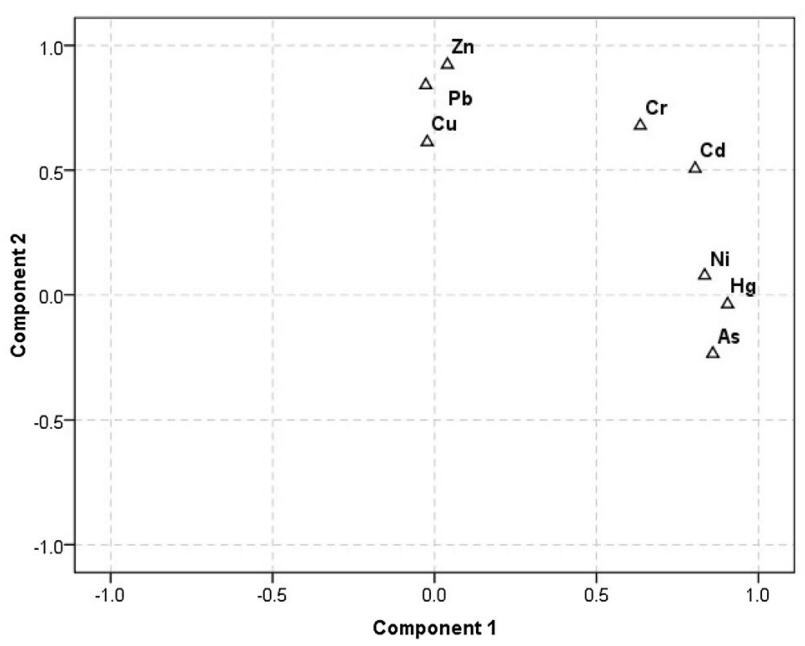

Fig. 2 Heavy metals loading scores of extracted components obtained for eight heavy metals in suburban topsoil in Kenya

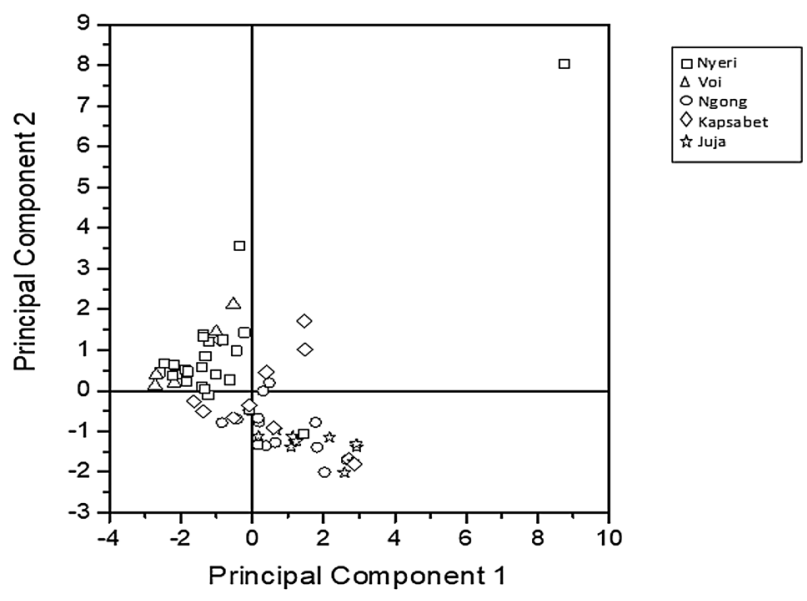

Fig. 3 Loading scores of extracted principal components in suburban topsoil in Kenya

explained $28.479 \%$ of the entire variance with an eigenvalue of 2.278. This module was highly associated with $\mathrm{Zn}$, $\mathrm{Cu}, \mathrm{Pb}$, and $\mathrm{Cr}$ (Fig. 2) and was referred to as the anthropogenic component. Besides, it was observed that $\mathrm{Cr}$ showed almost equal loading values in the two derived components. Figure 3 illustrates the loading plots of PC1 and $P C 2$ for the five towns. The sampling sites depicted high positive loading values of $\mathrm{PC} 2$.

For clearer observation of data, cluster test was done as a confirmation test for source identification results. Generally, the hierarchical cluster analysis sorts data into clusters based on their strong associations [34]. According to this analysis, the smaller the value on the axis, the greater the significance of the association. With reference to Fig. 4, the relationship between and among heavy metals groups derived two clusters similar to PCA results above (Fig. 2).
The first cluster comprised of $\mathrm{Cd}, \mathrm{Hg}, \mathrm{Ni}$, and $\mathrm{Cr}$ and $\mathrm{As}$ which corresponded with PCA results indicating a lithogenic source of pollution. The second cluster consisted of $\mathrm{As}, \mathrm{Cu}, \mathrm{Pb}$, and $\mathrm{Zn}$ defining the anthropogenic factor.

\subsection{Correlation analysis}

The correlation among the heavy metals was assessed to determine the association between heavy metals and to identify the origin of pollution in the five towns (Table 3). At the 0.01 significant level metal pairs; Ni versus $C r, Z n$ versus $C r$, As versus $C r, H g$ versus $C r$, Pb versus $\mathrm{Cr}, \mathrm{Ni}$ versus $\mathrm{As}, \mathrm{Ni}$ versus $\mathrm{Cd}$, Ni versus $\mathrm{Hg}$, $\mathrm{Cu}$ versus $\mathrm{Zn}$, $C u$ versus $P b, Z n$ versus $C d, Z n$ versus $P b$, As versus $C d$, As versus $\mathrm{Hg}, \mathrm{Cd}$ versus $\mathrm{Hg}$, and $\mathrm{Cd}$ versus $\mathrm{Pb}$ showed a significant positive association. The strongest association was observed between $\mathrm{Cd}$ versus $\mathrm{Cr}\left(r^{2}=0.841\right)$, and $\mathrm{Pb}$ versus $\mathrm{Zn}\left(r^{2}=0.701\right)$. Additionally, at the 0.05 significant level, two heavy metal pair elements; $\mathrm{Cr}$ versus $\mathrm{Cu}, \mathrm{Cd}$ versus $\mathrm{Cu}$ showed a positive association. TOC was positively correlated with $\mathrm{Cr}$ and $\mathrm{Cu}$ at the 0.05 significant level and with $\mathrm{Zn}, \mathrm{Pb}$, and $\mathrm{As}$ at the 0.01 significant level.

\subsection{Health implications of heavy metal contaminants in Kenya}

The probable environmental risk index (RI) from metal pollution in the topsoil of municipals in Kenya was assessed. The severity of pollution in the towns decreased in the order Juja $>$ Ngong $>$ Kapsabet $>$ Nyeri $>$ Voi. The risk index value $\left(E_{f}^{i}\right)$ for a single heavy metal reported values between 0.01 and 15.87 (Table 4). These values were less than the Hakanson's risk level $\leq 40$. Nevertheless, $\mathrm{Pb}$ in Juja town and As in Ngong town showed higher values (Fig. 5). Correspondingly, the metal of concern in Kapsabet, and Voi was As, while Cd was significant in Nyeri. Overall the summation values of risk index (RI), in descending order were $19.17,15.82,8.74,1.73$, and 1.67 for Juja, Ngong, Kapsabet, Nyeri, and Voi, respectively. These values of exposure index were less than the set Hakanson's RI risk level of $\leq 150$. Juja and Ngong showed high-risk values compared to Kapsabet, Nyeri, and Voi (Fig. 5).

\section{Discussion}

The result of heavy metal concentrations revealed the presence of pollution in the five study areas (Table 1). In comparison with the Tanzania standard values, all the heavy metal concentrations fell within the set standard limit. However, elevated concentrations of As pollution was noted in Juja town associated with metal smelting and the burning of fossil fuels [35]. Moreover, in many parts of 
Fig. 4 The cluster analysis result of heavy metals (a) and heavy metals and TOC (b) for the suburban topsoil in Kenya using Ward's method (a)

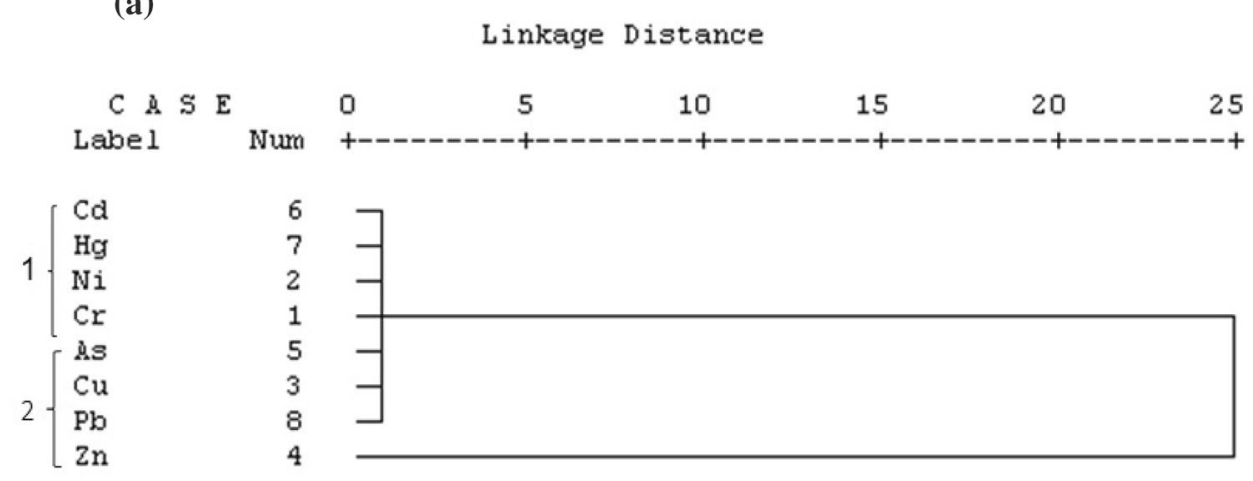

(b)

C À S E 0 10 15 20 25 Labe 1 Num 5 $-+$

$1\left\{\begin{array}{l}\mathrm{Cd} \\ \mathrm{Hg} \\ \mathrm{Ni} \\ \mathrm{TOC} \\ \mathrm{Cr}\end{array}\right.$
$2\left\{\begin{array}{l}\mathrm{As} \\ \mathrm{Cu} \\ \mathrm{Pb} \\ \mathrm{Zn}\end{array}\right.$

Table 3 Pearson correlation matrix of heavy metals and TOC for suburban soils of Kenya
Table 4 Risk calculations for heavy metals in the suburban soils of Kenya

\begin{tabular}{llllllllll}
\hline & $\mathrm{TOC}$ & $\mathrm{Cr}$ & $\mathrm{Ni}$ & $\mathrm{Cu}$ & $\mathrm{Zn}$ & $\mathrm{As}$ & $\mathrm{Cd}$ & $\mathrm{Hg}$ & $\mathrm{Pb}$ \\
\hline $\mathrm{TOC}$ & 1 & $0.280^{*}$ & 0.005 & $0.243^{*}$ & $0.579^{* *}$ & $-0.427^{* *}$ & 0.172 & -0.141 & $0.490^{* *}$ \\
$\mathrm{Cr}$ & & 1 & $0.583^{* *}$ & $0.306^{*}$ & $0.650^{* *}$ & $0.354^{* *}$ & $0.841^{* *}$ & $0.493^{* *}$ & $0.509^{* *}$ \\
$\mathrm{Ni}$ & & & 1 & 0.069 & 0.073 & $0.562^{* *}$ & $0.620^{* *}$ & $0.689^{* *}$ & 0.034 \\
$\mathrm{Cu}$ & & & & 1 & $0.411^{* *}$ & -0.074 & $0.271^{*}$ & -0.062 & $0.338^{* *}$ \\
$\mathrm{Zn}$ & & & & & 1 & -0.215 & $0.530^{* *}$ & 0.022 & $0.701^{* *}$ \\
$\mathrm{As}$ & & & & & & 1 & $0.599^{* *}$ & $0.720^{* *}$ & -0.171 \\
$\mathrm{Cd}$ & & & & & & & 1 & $0.687^{* *}$ & $0.353^{* *}$ \\
$\mathrm{Hg}$ & & & & & & & & 1 & -0.012 \\
$\mathrm{~Pb}$ & & & & & & & & & 1 \\
\hline
\end{tabular}

${ }^{*}$ Correlation is significant at the 0.05 level

${ }^{* *}$ Correlation is significant at the 0.01 level

\begin{tabular}{lllrrrrrrrr}
\hline & \multicolumn{9}{l}{ Potential ecological risk indices of heavy metals $\left(E_{f}^{i}\right)$} & \multicolumn{3}{c}{$\mathrm{Rl}$} \\
\cline { 2 - 8 } & $\mathrm{Zn}$ & $\mathrm{Cu}$ & \multicolumn{1}{c}{$\mathrm{As}$} & $\mathrm{Pb}$ & $\mathrm{Cr}$ & $\mathrm{Ni}$ & $\mathrm{Cd}$ & $\mathrm{Hg}$ & \\
\hline Juja & 0.03 & 0.04 & 0.46 & 15.87 & 0.04 & 0.03 & 0.04 & 2.67 & 19.17 \\
Ngong & 0.04 & 0.06 & 12.98 & 0.02 & 0.02 & 0.04 & 2.33 & 0.33 & 15.82 \\
Kapsabet & 0.07 & 0.04 & 6.67 & 0.05 & 0.02 & 0.03 & 1.58 & 0.28 & 8.74 \\
Nyeri & 0.10 & 0.08 & -0.08 & 0.07 & 0.02 & 0.02 & 1.37 & 0.17 & 1.73 \\
Voi & 0.04 & 0.03 & 1.04 & 0.05 & 0.01 & 0.01 & 0.38 & 0.11 & 1.67 \\
\hline
\end{tabular}

Kenya, the use of wood fuel and charcoal for heating and cooking is a cheap alternative to the use of electricity and gas stove; hence, the probable source of arsenic. In Ngong town, prominent metal concentrations were linked to the toxic waste from the dumpsite in the vicinity. Studies show that waste matter from dumpsites contains toxic metal 


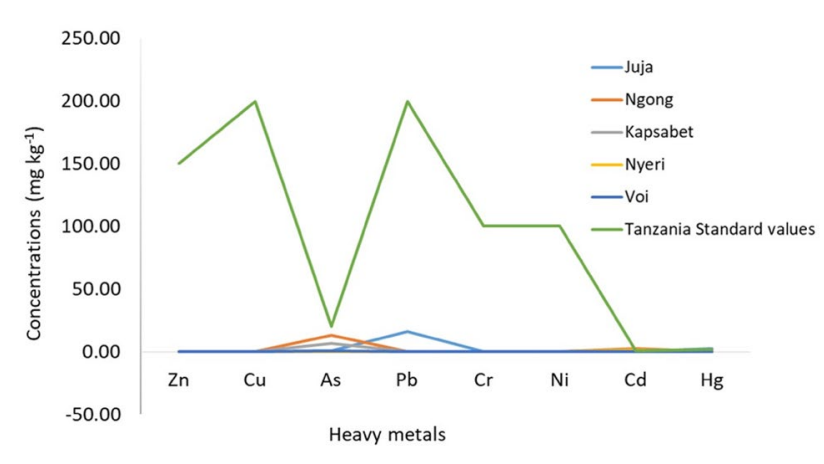

Fig. 5 Toxicity indices of heavy metals in suburban topsoil in Kenya

elements and is leached into soils leading to an upsurge of metal contamination [36]. The toxic waste from the dumpsite was, therefore, a key contributing factor to the high heavy metal pollution in the area. The use of wastewater in areas near the dumpsite was also observed. Farmers in the area are more focused on maximizing yields with less regard to environmental conservation [37]. Thus, the sustained use of wastewater in crop irrigation results in the buildup and consequently, the bioamplification of heavy metals in the food chain [38]. Tea farming activities in conjunction with the existence of tea factories in Kapsabet town were the probable sources of metal pollution in the area. Previous research indicates that the extensive application of livestock manure in farming and the improper disposal of industrial waste matter are particularly potent sources of $\mathrm{Ni}$ and $\mathrm{Hg}$ in soil [39]. Heavy metals contamination in Nyeri town was linked to industrial waste and farming activities [2]. Nyeri is renowned for its tea and coffee production with several manufacturing industries in the vicinity. Research findings further indicate that over-application of fertilizer, manure, and biosolids increase toxic metal levels in soils and plants $[40,41]$. In Voi town, the heavy metal contamination was associated with farming activities at the vast sisal plantations in the area. Another significant pollution source was from traffic emissions linked to the busy Nairobi Mombasa route that, cuts across Voi town. Road transport has previously been described to be a significant source of heavy metals in soils, especially lead pollution [42].

In the five study areas, the soil contamination was associated with the improper disposal of municipal wastes, which continues to be a problem that plagues overpopulated environments in Kenya. This is mainly due to the lack of proper recycling methods in municipals and the lack of strong laws for environmental protection in Kenya. These towns also revealed the continued application of commercial fertilizer and biosolids in farms resulting in the introduction of heavy metals which leach into the soil and could potentially be biomagnified into the food chain.
In comparison with other locations, the concentrations of heavy metals in this study were found to be higher than those in Eldoret, Kenya ( $\mathrm{Zn} \mathrm{2.37,} \mathrm{Pb} \mathrm{0.68,}$ Cu 0.35, Cd 0.04, and $\mathrm{Hg} 0.01 \mathrm{mg} \mathrm{kg}^{-1}$ ) [43]; in Samburu, Kenya $\mathrm{Cr}$ (2.65 $\mathrm{mg} \mathrm{kg}^{-1}$ ) [44]; and in Beijing (Zn 65.6, Cd $0.15 \mathrm{mg} \mathrm{kg}^{-1}$ ) [45]. In contrast, the concentration of some of the heavy metals from other regions showed higher values than our study including; Samburu, Kenya ( $\mathrm{Zn} 376.3$, $\mathrm{Pb} 0.68$, and $\mathrm{Cd} 0.04 \mathrm{mg} \mathrm{kg}^{-1}$ ) [44]; Kabwe, Zambia ( $\mathrm{Zn}$ 106, Pb 759, Cu 58.2, and Cd $22.3 \mathrm{mg} \mathrm{kg}^{-1}$ ) [46]; Ibadan, Nigeria (Zn 228.6 Pb 95.1, As 3.9, Cu 46.8, Ni 20.2, and Cd $8.4 \mathrm{mg} \mathrm{kg}^{-1}$ ) [47]; and in Pretoria, South Africa (Zn 67.01, $\mathrm{Pb}$ 62.2, Cu 88.1, Cr 34.06, and Cd $2.23 \mathrm{mg} \mathrm{kg}^{-1}$ ) [48].PCA results (Fig. 2) revealed moderate concentration levels of $\mathrm{Ni}, \mathrm{As}, \mathrm{Cd}$, and $\mathrm{Hg}$ in $\mathrm{PC} 1$ and were referred to as the lithogenic factor. The accumulation of $\mathrm{Ni}$ in soil was linked to the weathering of rock [49] and wind dust [50]. Arsenic pollution was linked to its occurrence in rocks, which is then released through disintegration [51]. Cadmium was linked to the fragmentation of sedimentary rocks while $\mathrm{Hg}$ was associated with geologic formations [52].

The second component, $\mathrm{PC2}$, associated with $\mathrm{Zn}, \mathrm{Cu}$, $\mathrm{Pb}$, and $\mathrm{Cr}$. With reference to Table $1, \mathrm{Zn}, \mathrm{Cu}, \mathrm{Pb}$, and $\mathrm{Cr}$ also showed higher mean values in all the sites. This component was thus referred to as the anthropogenic factor. Our results also noted that $\mathrm{Cr}$ had equal loading scores in both components and could be released from both natural and anthropogenic sources, including the disintegration of rocks and the improper disposal of $\mathrm{Cr}$ containing waste matter [53]. The anthropogenic input of toxic metals in the studied regions could be from three sources. The first significant pathway is via agricultural activities. In Kenya, agronomy plays a crucial role in the provision of food for the local community and the generation of income. Both large-scale and small-scale farming are practiced in various parts of the country. For example, Kapsabet and Nyeri towns are major tea growing regions in Kenya. Likewise, in Voi town, sisal farming is done in vast acres of land, while maize farming is practiced in Juja and Ngong area. These agricultural practices may involve the use of commercial fertilizers and livestock manure, which are potential sources of soil heavy metal pollution [54-56].

Secondly, the burning of fossil fuels for cooking and improper disposal of municipal waste are some of the potential sources of heavy metal contamination. For instance, in Ngong town, there is a massive dumpsite covering several acres of land where waste is continually being deposited. Similarly, in Kapsabet town, there exists a dumpsite that poses a potential health hazard to the public. In Juja town, the lack of an efficient waste management facility results in wastes and litter routinely being dumped in open spaces. In many of these townships in Kenya, the disposal of garbage usually involves 
burning or discarding waste matter in public land. This process has resulted in overflowing heaps of waste matter, posing a potential health threat to the surrounding communities.

Thirdly, inadequate drainage facilities in the townships have ensued inappropriate disposition of industrial and domestic effluents. In many parts of the country, lack of a proper drainage system is still a concern [57]. Industries and residential homes are continually releasing effluents into the environment [58]. For example, in Kapsabet and Nyeri towns, tea and coffee manufacturing factories are the core industries. These industries may have an impact on the pollution of the ecosystem and consequently pose harm to human health.

PCA examination of the five sampling sites (Fig. 3) revealed that human activities had a fundamental role in the pollution of soil. In Kapsabet town, both the natural and anthropogenic factors influenced the contamination of heavy metals. Whereas, human activities showed a more significant impact, especially in Nyeri and Voi towns.

Cluster analysis test showed similar results with PCA indicating that heavy metals were derived from both lithogenic and anthropogenic sources. TOC association with the heavy metals in the first cluster indicated that the carbon content of the soil was an important factor in the availability and distribution of these metals. This is consistent with previous reports $[34,59,60]$.

Pearson correlation test (Table 3 ) showed that there was a significant association derived among the eight heavy metals signifying similar pollution sources. Generally, the apportionment of heavy metals was attributed to several pollution sources, including human activities such as the use of crop pesticides, and the improper disposal of industrial and municipal waste and from natural sources. The correlation of TOC with heavy metals indicated that TOC played a crucial role in the adsorption and the dispersion of heavy metals in soil.

The probable environmental risk index (Table 4) indicated a low level of ecological toxicity. However, the elevated levels of $\mathrm{Pb}$ in Juja tend to persist in the environment posing a danger to human health [61]. Similarly, high levels of As in Ngong town poses a threat to human well-being and can be carcinogenic [62]. Correspondingly, levels of As and Cd in Kapsabet and Voi and the levels of $\mathrm{Cd}$ in Nyeri were of concern. This further points out that the continued accumulation and biomagnification of these elements in the food chain could threaten the health of the surrounding communities. The overall cumulative values of exposure index indicated low ecological risk. Nonetheless, the cumulative heavy metal contamination of Juja and Ngong areas posed a potential health threat to the surrounding communities compared to Kapsabet, Nyeri, and Voi.

\section{Conclusion}

Monitoring of heavy metal compounds in the soil provides an effective means to evaluate their concentrations and consequently compute their effect on the ecological unit. In this study, the levels of metal elements in the soils of the selected towns were found to be within the set standard values of Tanzania. When compared to heavy metals in other regions, single heavy metals in our study depicted higher concentration levels indicating a need for control measures to be implemented. Overall, $\mathrm{Zn}$ showed high mean concentrations in all the study sites and was predominantly influenced by human activities. The source apportionment of metal concentrations in the suburban soils further illustrated that human activities had a strong impact on heavy metal pollution in the soils. Additionally, Pearson correlation test established an inter-relationship among metal pairs indicating similar pollution origin. The incongruous disposal of waste, intensive farming practices, and combustion of fossil fuels was revealed to be the main pollution sources. The ecological risk indices disclosed that the threat posed to the surrounding environment was low. However, single heavy metals $\mathrm{Pb}$ and $\mathrm{As}$ are of particular concern and should be observed closely. Moreover, the heavy metal ecological threat of Ngong and Juja was found to be higher than the other studied areas. The findings from this study suggested the need for regular monitoring of metal pollutants in the soil, as industrialization and urbanization activities intensify. Additionally, it is necessary to implement remediation strategies to prevent the accumulation of heavy metals in the environment.

Acknowledgements This research was supported and funded by National Key Research and Development Program of China, Grant Number [2018YFD0900604], Guangdong Province Universities and Colleges Pearl River Scholar Funded Scheme (2018), the SinoAfrica Joint Research Centre, the Chinese Academy of Sciences (Y623321 K01). We appreciate the support of the Chinese Academy of Sciences-The World Academy of Sciences (CAS-TWAS) President's Fellowship program for Doctoral Program.

\section{Compliance with ethical standards}

Conflict of interest The author declares that they have no conflict of interest.

\section{References}

1. Tchounwou PB, Yedjou CG, Patlolla AK, Sutton DJ (2012) Heavy metals toxicity and the environment. Expert Suppl 101(101):133-164

2. He ZL, Yang XE, Stoffella PJ (2005) Trace elements in agroecosystems and impacts on the environment. J Trace Elements Med Biol 19(2):125-140 
3. Yabe J, Ishizuka M, Umemura T (2010) Current levels of heavy metal pollution in Africa. J Vet Med Sci 72(10):1257-1263

4. Imperato $M$, Adamo $P$, Naimo $D$, Arienzo $M$, Stanzione $D$, Violante $P$ (2003) Spatial distribution of heavy metals in urban soils of Naples city (Italy). Environ Pollut 124(2):247-256

5. Xia X, Chen X, Liu R, Liu H (2011) Heavy metals in urban soils with various types of land use in Beijing, China. Js Hazard Mater 186(28):2043-2050

6. Mungai TM, Owino AA, Makokha VA, Gao Y, Yan X, Wang J (2016) Occurrences and toxicological risk assessment of eight heavy metals in agricultural soils from Kenya, Eastern Africa. Environ Sci Pollut Res 23(18):1-9

7. Wuana RA, Okieimen FE (2011) Heavy metals in contaminated soils: a review of sources, chemistry, risks and best available strategies for remediation. ISRN Ecol 2011:20

8. Kirpichtchikova Tatiana $A$, Alain $M$, Lorenzo $S$, Frédéric $P$, Marcus Matthew A, Jacquet T (2006) Speciation and solubility of heavy metals in contaminated soil using X-ray microfluorescence, EXAFS spectroscopy, chemical extraction, and thermodynamic modeling. Geochim Cosmochim Acta 70(9):2163-2190

9. Zheng N, Liu J, Wang Q, Liang Z (2010) Health risk assessment of heavy metal exposure to street dust in the zinc smelting district, Northeast of China. Sci Total Environ 408(4):726-733

10. Bordajandi LR, Gema G, Esteban A, Josep R, Julián B, María José $G$ (2004) Survey of persistent organochlorine contaminants (PCBs, PCDD/Fs, and PAHs), heavy metals ( $\mathrm{Cu}, \mathrm{Cd}, \mathrm{Zn}, \mathrm{Pb}$, and $\mathrm{Hg}$ ), and arsenic in food samples from Huelva (Spain): levels and health implications. J Agric Food Chem 52(4):992-1001

11. Chibuike GU, Obiora SC (2014) Heavy metal polluted soils: effect on plants and bioremediation methods. Appl Environ Soil Sci 2014:12

12. United Nations Environmental Program (UNEP) (2007) Environmental pollution and impacts on public health: Implications of the Dandora Municipal Dumping Site in Nairobi, Kenya. http:// www.unep.org/urban_environment/PDFs/DandoraWasteDum p-ReportSummarypdf Accessed 4 Dec 2018

13. Sedki A, Lekouch N, Gamon S, Pineau A (2003) Toxic and essential trace metals in muscle, liver and kidney of bovines from a polluted area of Morocco. Sci Total Environ 317(1-3):201-205

14. Lekouch N, Sedki A, Bouhouch S, Nejmeddine A, Pineau A, Pihan JC (1999) Trace elements in children's hair, as related exposure in wastewater spreading field of Marrakesh (Morocco). Sci Total Environ 243-244:323-328

15. Adimado AA, Baah DA (2002) Mercury in human blood, urine, hair, nail, and fish from the Ankobra and Tano river basins in southwestern Ghana. Bull Environ Contam Toxicol 68(3):339-346

16. Jumba IO, Kisia SM, Kock R (2007) Animal health problems attributed to environmental contamination in lake Nakuru National Park, Kenya: a case study on heavy metal poisoning in the Waterbuck Kobus ellipsiprymnus defassa (Ruppel 1835). Arch Environ Contam Toxicol 52(2):270-281

17. Abouarab AAK (2001) Heavy metal contents in Egyptian meat and the role of detergent washing on their levels. Food Chem Toxicol 39(6):593-599

18. Hang X, Wang H, Zhou J, Ma C, Du C, Chen X (2009) Risk assessment of potentially toxic element pollution in soils and rice (Oryza sativa) in a typical area of the Yangtze River Delta. Environ Pollut 157(8):2542-2549

19. Maas S, Scheifler R, Benslama M, Crini N, Lucot E, Brahmia Z, Benyacoub S, Giraudoux P (2010) Spatial distribution of heavy metal concentrations in urban, suburban and agricultural soils in a Mediterranean city of Algeria. Environ Pollut 158(6):2294-2301

20. Zhang J, Deng H, Wang D, Chen Z, Xu S (2013) Toxic heavy metal contamination and risk assessment of street dust in small towns of Shanghai suburban area, China. Environ Sci Pollut Res 20(1):323-332
21. Taghipour H, Mosaferi M, Armanfar F, Gaemmagami SJ (2013) Heavy metals pollution in the soils of suburban areas in big cities: a case study. Int J Environ Sci Technol 10(2):243-250

22. Nyamwange $M$ (1995) Population growth and development: the Kenyan experience. Scand J Dev Altern 14(1-2):149-160

23. Chibuike GU, Obiora SC (2014) Heavy metal polluted soils: effect on plants and bioremediation methods. Appl Environ Soil Sci 2014:243-254

24. Jiang L, Li Z (2016) Urbanization and the change of fertilizer use intensity for agricultural production in Henan Province. Sustainability $8(2): 186$

25. Ferronato $\mathrm{N}$, Torretta $\mathrm{V}$ (2019) Waste mismanagement in developing countries: a review of global issues. Int J Environ Res Public Health 16(6):1060

26. Ovuka M (2000) Land use changes in Central Kenya from the 1950s: A possibility to generalise? GeoJournal 51(3):203-209

27. Bai J, Cui B, Chen B, Zhang K, Deng W, Gao H, Xiao R (2011) Spatial distribution and ecological risk assessment of heavy metals in surface sediments from a typical plateau lake wetland, China. Ecol Model 222:301-306

28. Guo W, Liu X, Liu Z, Li G (2010) Pollution and potential ecological risk evaluation of heavy metals in the sediments around Dongjiang Harbor, Tianjin. Proc Environ Sci 2:729-736

29. Hakanson $L$ (1980) An ecological risk index for aquatic pollution control: a sedimentological approach. Water Res 14(8):975-1001

30. Asuero AG, Sayago A, González AG (2006) The correlation coefficient: an overview. Crit Rev Anal Chem 36(1):41-59

31. Jolliffe IT (2002) Principal component analysis. J Mark Res 87(100):513

32. Tahri M, Benyaïch F, Bounakhla M, Bilal E, Gruffat JJ, Moutte J, Garcia D (2005) Multivariate analysis of heavy metal contents in soils, sediments and water in the region of Meknes (central Morocco). Environ Monit Assess 102(1):405-417

33. Szekely GJ, Rizzo ML (2005) Hierarchical clustering via joint between-within distances: extending ward's minimum variance method. J Classif 22(2):151-183

34. Su L, Liu J (2014) Multivariate analysis of heavy metal contamination in soil of Baiyangdian wetland in China. J Environ Account Manag 2(4):313-323

35. Shrivastava A, Ghosh D, Dash A, Bose S (2015) Arsenic contamination in soil and sediment in India: sources, effects, and remediation. Curr Pollut Rep 1(1):35-46

36. Njagi JM, Akunga DN, Njagi MM, Ngugi MP, Njagi EMN (2016) Heavy metal pollution of the environment by dumpsites: a case of Kadhodeki dumpsite. Int J Life Sci Sci Res 2(2):191-197

37. Odai SN, Mensah E, Sipitey D, Ryo S, Awuah E (2008) Heavy metals uptake by vegetables cultivated on urban waste dumpsites: case study of Kumasi, Ghana. Res J Environ Toxicol 2(2):92-99

38. Muchuweti M, Birkett JW, Chinyanga E, Zvauya R, Scrimshaw MD, Lester JN (2006) Heavy metal content of vegetables irrigated with mixtures of wastewater and sewage sludge in Zimbabwe: implications for human health. Agric Ecosyst Environ 112(1):41-48

39. Basta NT, Ryan JA, Chaney RL (2005) Trace element chemistry in residual-treated soil: key concepts and metal bioavailability. J Environ Qual 34(1):49-63

40. Atafar Z, Mesdaghinia A, Nouri J, Homaee M, Yunesian M, Ahmadimoghaddam M, Mahvi AH (2010) Effect of fertilizer application on soil heavy metal concentration. Environ Monit Assess 160(1-4):83

41. Sanayei Y, Ismail N, Talebi SM (2009) Determination of heavy metals in Zayandeh Rood River, Isfahan-Iran. World Appl Sci 6(9):1209-121

42. Kummer U, Pacyna J, Pacyna E, Friedrich R (2009) Assessment of heavy metal releases from the use phase of road transport in Europe. Atmos Environ 43(3):640-647 
43. Ngure V, Sitati N, Shisia S, Kinuthia G (2015) Assessment of heavy metals pollution in urban soils and the implications to consumers health. J Nat Sci Res 5(17):76-83

44. Salano EM (2007) Assessment of heavy metals pollution in soils and water of Samburu county, Nairobi. Kenyatta University. http://ir-library.ku.ac.ke. Accessed 21 Jan 2019

45. Zheng Y-M, Chen T-B, He J-Z (2008) Multivariate geostatistical analysis of heavy metals in topsoils from Beijing, China. J Soils Sediments 8(1):51-58

46. Tembo BD, Sichilongo K, Cernak J (2006) Distribution of copper, lead, cadmium and zinc concentrations in soils around Kabwe town in Zambia. Chemosphere 63(3):497-501

47. Odewande A, Abimbola A (2008) Contamination indices and heavy metal concentrations in urban soil of Ibadan metropolis, southwestern Nigeria. Environ Geochem Health 30(3):243-254

48. Olowoyo J, Van Heerden E, Fischer J (2013) Trace metals concentrations in soil from different sites in Pretoria, South Africa. Sustain Environ Res 23(2):93-99

49. Chauhan SS, Thakur R, Sharma GD (2008) Nickel: its availability and reactions in soil. $J$ Ind Pollut Control 24(1):1-8

50. lyaka YA (2011) Nickel in soils: a review of its distribution and impacts. Sci Res Essays 6(33):6774-6777

51. Garelick H, Jones H, Dybowska A, Valsamijones E (2009) Arsenic pollution sources. Rev Environ Contam Toxicol 197:17-60

52. Pacyna JM, Pacyna EG (2005) Anthropogenic sources and global inventory of mercury emissions. In: Percival JB (ed) Mercury: sources, measurements, cycles, and effects. Mineralogical Association of Canada, Ottawa

53. Lawrence SA (1995) Remedial options for metals-contaminated sites. Florida, Boca Raton

54. Raymond WA, Okieimen FE (2011) Heavy metals in contaminated soils: a review of sources, chemistry, risks and best available strategies for remediation. ISRN Ecol 2011:1-20
55. Onyatta JO, Huang PM (1999) Chemical speciation and bioavailability index of cadmium for selected tropical soils in Kenya. Geoderma 91(1-2):87-101

56. Thuy HTT, Tobschall HJ, An PV (2000) Distribution of heavy metals in urban soils: a case study of Danang-Hoian Area (Vietnam). Environ Geol 39(6):603-610

57. Toryila $T$ (2016) The effects of poor drainage system on road pavement: a review. Int J Innov Res Multidiscip Field 2:216-223

58. Moses A, Nyongesa D, Neyole E, Masinde E (2011) Effluent discharge by Mumias sugar company in Kenya: an empirical investigation of the pollution of River Nzoia. Sacha J Environ Stud $1: 1-30$

59. Gray JE, Theodorakos PM, Fey DL, Krabbenhoft DP (2015) Mercury concentrations and distribution in soil, water, mine waste leachates, and air in and around mercury mines in the Big Bend region, Texas, USA. Environ Geochem Health 37(1):35-48

60. Mbuvi HM (2013) Speciation of chromium and nickel in open-air automobile mechanic workshop soils in Ngara, Nairobi, Kenya. World Environ 3(5):145-154

61. Mtunzi FM, Dikio ED, Moja SJ (2015) Evaluation of heavy metal pollution on soil in Vanderbijlpark, South Africa. Int J Environ Monit Anal 3(2):44-49

62. Hossain MF (2006) Arsenic contamination in Bangladesh: an overview. Agric Ecosyst Environ 113(1):1-16

63. Kamunda C, Mathuthu M, Madhuku M (2016) Health risk assessment of heavy metals in soils from witwatersrand gold mining basin, South Africa. Int J Environ Res Public Health 13(7):663

Publisher's Note Springer Nature remains neutral with regard to jurisdictional claims in published maps and institutional affiliations. 